\title{
Recomponer el paisaje: evidenciar y denunciar ${ }^{1}$
}

\section{Recompose the Landscape: Evidence and Denounce}

\author{
Bruno Jara Ahumada \\ Magíster en Arte, Pensamiento y Cultura Latinoamericano, \\ Universidad de Santiago de Chile \\ bjara.ahumada@gmail.com
}

\section{Resumen}

La investigación plantea que el paisaje fue reiterativo en los testimonios visuales de la dictadura militar chilena. Por paisaje entenderemos una construcción visual, política y cultural que otorga densidad espacio-referencial a los relatos de la memoria. Bajo este marco, distinguimos una pugna de sentidos: primero, el autoritarismo instrumentalizó el paisaje para vehiculizar valores subterráneos y promover la legitimidad del régimen. Paralelamente, la resistencia generó paisajes denotativos, en clave acusatoria-testimonial, que concretizó en múltiples medios. En particular, se examinará un corpus compuesto de arpilleras y dibujos en prisión. Más allá de sus especificidades, se propone que una de las principales funciones que reúne a ambos conjuntos es su uso como dispositivo de evidencia y denuncia. Así, se intentará recomponer parte del paisaje disidente al hilvanar ciertas imágenes que dan cuenta del sustrato espacial de los hechos.

Palabras clave: paisaje, dictadura, testimonio, lugares, imágenes.

\begin{abstract}
The investigation states that the landscape was repetitive in the visual testimonies of the Chilean military dictatorship. By landscape it comprises a visual, political and cultural construction, which gives space-reference density to the memory accounts. In this context, we distinguish a struggle of meanings: first, authoritarianism instrumented the landscape to convey the subterranean values and promoted the legitimacy of the regime. At the same time, the resistance generated denotative landscapes, in an accusatory-testimony key, which materialized in endless means. Specifically, a corpus composed of arpilleras and drawings in prison will be examined. Beyond its specificities, we propose that one of the main functions that brings together both sets is its use as a device of evidence and denunciation. Thus, we will try to recompose part of the dissident landscape by weaving together certain images that account for the spatial substrate of the events.
\end{abstract}

Keywords: landscape, dictatorship, testimony, places, images.

1 Este artículo se inscribe en el proyecto de investigación "Formas narrativas del testimonio relatos de prisión política en Chile, Argentina, Uruguay y Brasil”, FONDECYT Regular No 1161551. 


\section{Introducción}

Junto a los crímenes y la violación sistemática de los derechos humanos, la dictadura militar en Chile disipó un proceso de rearticulación simbólica que se permeó hasta en lo cotidiano. De acuerdo con Gonzalo Leiva, se impulsó una "nueva memoria cultural" de modo coercitivo y explícito (93). Así, distintas estrategias confluyeron en el "golpe estético" (Errázuriz y Leiva), vale decir, una red de maniobras culturales que buscaron legitimar la autoridad de la ideología imperante. A través del control de los medios e imaginarios sociales (Errázuriz) la dictadura logró, en cierta medida, disimular y subvertir los estragos de la catástrofe. Desde una perspectiva situada, el paisaje sirvió a estos propósitos como instrumento pedagógico al estructurar y volcar nuevos valores sobre el espacio soberano (Tanács). Por paisaje comprenderemos una epistemología dinámica, la cual fluctúa entre las relaciones físicas (M. Santos) y la interpretación que se realiza -individual o colectivamente- de un referente dado (Maderuelo). Específicamente, examinaremos su representación visual o traducción gráfica concreta. Retomando nuestro contexto, el paisaje será también una construcción política y cultural capaz de otorgar densidad espacio-referencial a los relatos de la memoria. En este marco, distinguimos una pugna de sentidos que disputó el emplazamiento y la veracidad territorial de los sucesos, según las versiones de cada grupo.

Primero, mediante la internalización del armatoste patriótico, el oficialismo utilizó el paisaje para "inscribir la sociedad y el Estado autoritario en el orden de la naturaleza" (Jara, "Politizar" 241): la toma del poder fue necesaria y, peor aún, natural. A partir de este momento, Chile fue graficado como pura potencia, como una pila de avances refundacionalistas que se acercaban bajo el buen augurio del dictador. El paisaje se asoció "a las fronteras, al desarrollo económico, a la expansión marítima y a la soberanía en los extremos geográficos [...]" (246). También, buscando el paisaje típicamente chileno, la oficialidad recogió la historia plástica de la nación, la revaloración del Valle Central, el criollismo y los emblemas nacionales, entre varios. Finalmente, todo ese cúmulo, ajustado a diversos canales de transmisión, participó vivamente en la nueva epopeya del régimen: reinventar la tradición del país con apoyo de los elementos insignes.

Por otra parte, y pese al agreste panorama, existieron diversas propuestas reactivas a la supremacía visual del régimen. Durante los años que se mantuvo activa la opresión, el exilio, los delitos, las torturas y las desapariciones, numerosas imágenes espacio-referenciales emergieron cual paisajes disidentes. Aplicando las propuestas de Joan Nogué, estos desplazamientos podrían entenderse como un desajuste entre la experiencia y la representación o, también, como un conflicto entre aquello que se percibía y aquello que las personas deseaban, soñaban o tenían por referente (162). Ante el escenario coaptado por el heroísmo y la abundancia, la resistencia ubicó el horror, la hambruna y el despotismo. Vehiculizados en un sinfín de sustratos, estos paisajes instalaron nódulos de lucha que promovían clandestinamente la imperiosa necesidad de recuperar la democracia: afiches, panfletos, prensa alternativa y miles de 
fotografías que, entre muchas otras fórmulas, ayudaron a reunir y fortalecer la oposición. Todas esas imágenes, aún desde su ocultamiento, se fugaron más allá del control autoritario y por eso mismo testimonian - con igual o mayor fuerza que las fuentes textuales - las incontables ocasiones en las que se agraviaron las libertades civiles y la dignidad humana. A partir de este enjambre visual, nos dedicaremos a examinar dos conjuntos que todavía permanecen relativamente ausentes dentro de la crítica especializada: por una parte, las arpilleras —o composiciones textiles- elaboradas por distintos grupos de mujeres sin recursos y, en simultáneo, los dibujos de prisioneros políticos. A simple vista, el universo de estas formaciones posiciona materialidades y flujos de transmisión dispares e incluso contextualmente contradictorios. Ahora bien, más allá de conjeturar una semiótica particular a cada soporte, la mirada general que los aunará será su funcionalización como testimonio visual: buscaremos la potencialidad histórica y discursiva de estas imágenes según los usos sociales que estarían cumpliendo, independientemente de sus especificidades.

Para ello, propongo que las representaciones no-oficiales propiciaron un paisaje denotativo en clave acusatoria-testimonial. Dentro de sus funciones, indagaremos la articulación del paisaje como aparejo de evidencia y denuncia: por encima de la cordillera y los valles, la resistencia tejió y dibujó la catástrofe. Así, entre sus tópicos, encontramos centros de detención y/o tortura, parajes urbanos, manifestaciones sociales y redadas, entre otros. Ahora bien, debo advertir que esta funcionalización es partícipe de un interconectado sistema hermenéutico. Se entiende que estos testimonios enhebran aristas que desbordan la delación: vinculadas, por ejemplo, con la reconstitución de las afectividades quebradas tras el trauma. Por lo mismo me centraré exclusivamente en imágenes de evidencia o denuncia, postergando así el desarrollo de otras vistas. Finalmente, la directriz analítica constituirá una mirada atemporal a la creación de las obras y se concentrará en sus mensajes gráficamente encriptados, no así en las intenciones - quizás inaccesibles- de sus autores. Dicho esto, los alcances pertinentes al rol de género o a la medialidad no serán atendidos.

\section{Evidenciar y denunciar}

Para John Beverly el testimonio es, a modo muy escueto, una narración contada en primera persona gramatical por un sujeto quien es a la vez el protagonista, o testigo, de su propio relato (9). Aun cuando esta descripción proviene de la experiencia textual, el mismo autor reconoce que el género testimonial excede las tipologías literarias. En consecuencia, las imágenes pueden ser escrituras testimoniales de resistencia en la medida que son los mismos creadores quienes narran sus vivencias. Dicho esto, no es ningún secreto que las imágenes fueron utilizadas como dispositivos para evidenciar y denunciar. En efecto, esta función tuvo por objeto dar a conocer, ilustrar y levantar información respecto de la catástrofe y las vejaciones en contra de la 
humanidad que operaron en distintos ejes y lugares del territorio. Tanto los dibujos en prisión como las arpilleras informaron sobre los acontecimientos situados que se sufrieron durante la dictadura. Mediante los paisajes no-oficiales, dichas imágenes acusaron que estos crímenes fueron escenificados a lo largo y ancho del país, en una paradigmática regionalización del horror. Muchas veces el paisaje fue un mero fondo impreciso sobre el cual se montó la masacre o los problemas económicos de la época como el hambre y la cesantía. Otras veces, el paisaje reveló detalles perniciosos sobre los centros de detención y/o tortura, los sectores específicos de la ciudad en donde se cometieron delitos en contra de la humanidad, o la meticulosa descripción física de esos inmuebles y sus entornos. A modo general, estas imágenes probaron y demostraron las injusticias sociales, la marginalización y la escasez vivida en los sectores más vulnerables, la existencia concreta de los centros de detención, la desaparición de miles de personas y los sitios específicos en donde se les vio por última vez y, en suma, ayudaron a frustrar las estrategias de ocultamiento al divulgar imágenes contrarias a la representación-país proyectada por la dictadura.

\section{Crímenes, represión o violencia situada en lugares específicos}

Quizás el uso más habitual de las imágenes disidentes fue la instrumentalización cometida para describir crímenes, represión o violencia situada en lugares puntuales y a veces momentos específicos de Chile. La mayoría de las ocasiones estos diseños acudieron al paisaje de manera directa para evidenciar las ciudades, edificios, monumentos o lugares geográficos que fueron puestos al servicio de la violencia sistémica. Dentro del amplio corpus de dibujos y arpilleras, encontramos centros de detención y/o tortura en distintas regiones de Chile, muchos de los cuales hoy ya no existen en la retina social - ya sea porque fueron destruidos, olvidados o debidamente encubiertos-, pero también hallamos algunos sitios que todavía conservan la memoria viva de las atrocidades que hospedaron tras sus muros. Por mencionar unos pocos, entre los 1.168 centros de detención y/o tortura —olvidados o no- existen dibujos y arpilleras que representaron a Isla Dawson, Ritoque, Chacabuco, Lonquén, Pisagua, Villa Grimaldi, el Estadio Nacional, etcétera. Ya que la mayoría de los centros se mantuvieron en la clandestinidad y el sigilo, la potencia testimonial de esta subcategoría adquiere mucho más valor pues delató la existencia concreta de esos focos del horror y reveló, simultáneamente, la fisonomía oculta del proyecto político implantado por la Junta de Gobierno.

En esta misma clave, las arpilleras - y no tanto así los dibujos- explicitaron varios crímenes de Estado reconocidos por sus exactas coordenadas dentro de las ciudades: el disparo a la estudiante y pianista María Paz Santibáñez frente al Teatro Municipal de Santiago; el asesinato de Víctor Jara en el antiguo Estadio Chile; dos de los degollados - Manuel Guerrero y José Parada — son secuestrados frente al colegio 
FIGURA 1

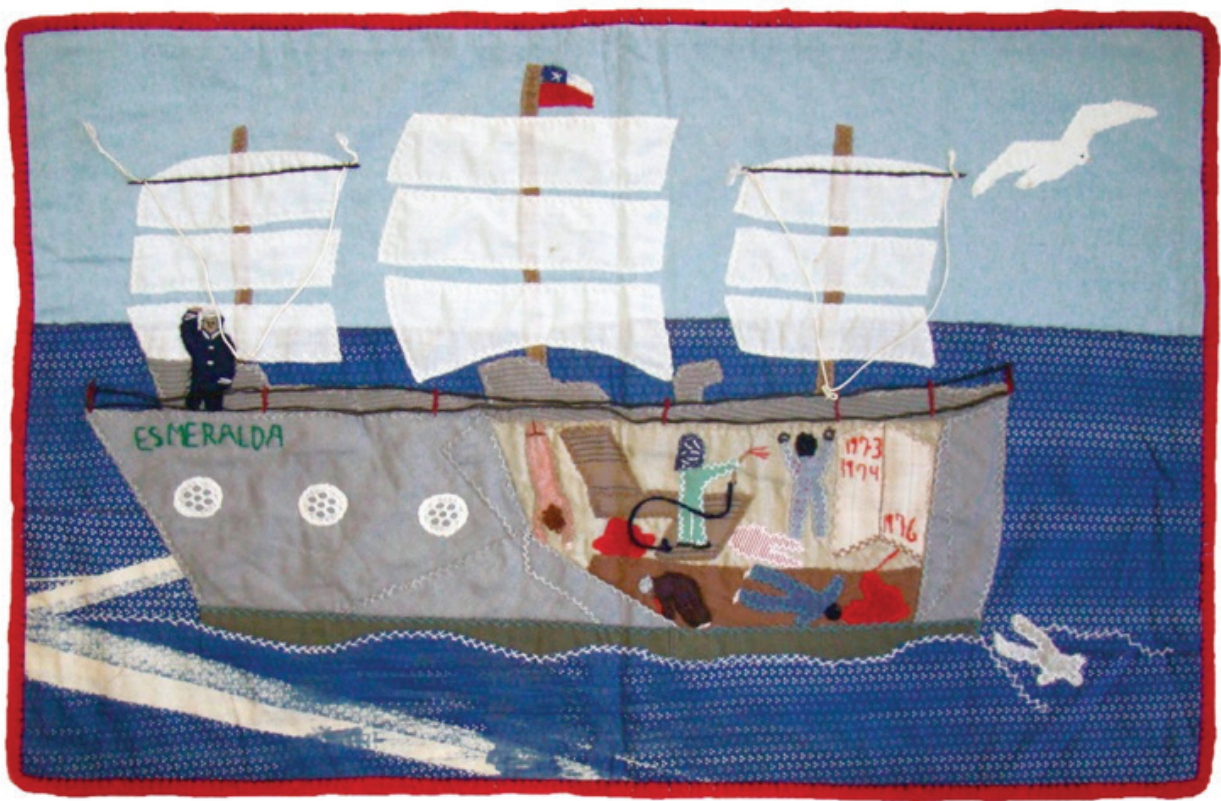

Tortura y crímenes en la Esmeralda, 1973-1990 (Acumulación).

Fuente: Museo de la Memoria y los Derechos Humanos (ммDH), Colección Isabel Morel.

Latinoamericano en Providencia, y sus cuerpos aparecieron junto al de Santiago Nattino en Quilicura; la inmolación de Sebastián Acevedo en la Plaza de la Independencia de Chile, en la ciudad de Concepción; entre tantos otros. No obstante, para los efectos de esta investigación, la arpillera titulada Tortura y crímenes en la Esmeralda [figura 1] introduce una potente tensión paisajística entre los lugares socialmente significados y los terribles usos que admitieron sus límites espaciales.

El buque escuela Esmeralda, también conocido como la "dama blanca”, es el navío por antonomasia de la Armada chilena. Con una tradición que remonta a 1791, y operando desde mediados del siglo pasado como un crucero de instrucción permanente, consiste sin duda en la máxima insignia de la valentía y el poderío oceánico de la nación: aunque no fue siempre el mismo barco, junto a sus cinco antepasados ${ }^{2}$ resistió los pasos triunfales de las glorias navales y sus bélicas hazañas. No obstante,

2 Fragata Esmeralda $1^{\circ}$ (1791), luego recibe el nombre de Valdivia; Corbeta Esmeralda 2० (1854); Crucero Esmeralda $3^{\circ}$ (1884); Crucero Esmeralda $4^{\circ}$ (1896), posteriormente bautizada como Baquedano en 1952; Fragata Esmeralda $5^{\circ}$ (1944); Buque Escuela Esmeralda 6º desde 1954 (Armada de Chile). 
pocos reconocen que ese mismo barco, heredero prístino de la patria y sus valores, fue utilizado como centro de detención y/o tortura mientras estuvo detenido en el puerto de Valparaíso. Sumados a aquel, otros buques de la Armada como el Lebu y el Maipo, y también la Academia de Guerra Naval (J. Santos, "La reconfiguración" 147), se reconfiguraron para admitir los mismos usos del horror. Todas ellas son estructuras paradójicas: en un principio fueron erguidas para fortalecer la imagen de la Armada pero, sin embargo, actualmente cuentan con una hoja de vida deshonrada: esconden cierta verdad que ya no se pronuncia, que se decidió concienzudamente dejar al margen; lugares que se contradijeron a sí mismos al albergar las acciones más infames de la dictadura. La memoria oficial, por cierto, no revela los antecedes de la matanza. Vista así, la Esmeralda representa un caso paradigmático que se inscribe en lo que José Santos denomina una "retroconversión". Es decir, el "proceso por el cual algunos lugares, habiendo sido utilizados como Centro de Detención y/o Tortura, luego se pretende que vuelvan a tener su sentido original; recuperan su finalidad inicial" ("Los centros" 265). El horror y sus huellas fueron exterminadas de la coraza del navío: nada suscita una voluntad por memorializar el pasado que allí aconteció.

Visualmente, la arpillera ubica al buque en el centro de la composición. El océano, el cielo despejado y el barco mismo son los únicos tres elementos paisajísticos presentes. El uso textual de la palabra Esmeralda en color verde y situada en el lado izquierdo actúa como evidencia irrefutable de que el barco que presenciamos es justamente aquél y no otro. Exceptuando un ave blanca en la esquina superior derecha, que podría tratarse de una gaviota, no hay otros distractores. A simple vista, destacan dos niveles de lectura: el exterior y el interior. La tensión de la cual hablábamos antes, esa crisis de la representación entre experiencias y significaciones entrecruzadas del lugar (Nogué), se encarna aquí ya que mientras el buque se presenta reluciente y aparentemente normal por afuera, en el interior asoman los crímenes y la tortura. La dama blanca mantiene su blindaje intacto y esplendoroso, deslumbra con toda su omnipresencia patriótica. Solo una señal de la superficie revela las atrocidades que ocultan sus paredes: un cuerpo anónimo color blanco que flota en la esquina inferior derecha. Fuera de ello, la hegemonía imperante de la patria se materializa por lo menos de tres modos. Primeramente, sobre el mástil central o el palo mayor ${ }^{3}$ flamea la bandera chilena. Además de reforzar la legitimidad oficial del barco, interpreto este símbolo como una sinécdoque visual: es la "parte" que evoca al "todo", es decir, mediante la bandera leemos al aparato dictatorial completo que es capaz de autorizar y avalar la ejecución del nuevo orden a cualquier precio. Se debe limpiar y eliminar lo que estorba: el fin justifica los medios.

En segundo lugar, vemos en el costado izquierdo a un marino, quizás el capitán, quien mira hacia el horizonte mientras permanece en la cubierta de la proa. La figura

3 Se representan solo tres de los cuatro mástiles del buque. 
humana sacude o levanta su mano derecha apuntando hacia a la cabeza: la clásica formación mediante la cual los militares saludan al estar cumpliendo sus funciones. Dicha rectitud puede ser leída bien como un distractor que desmiente, a través de la autoridad y la serenidad, lo que esconde el fondo del barco. O bien, en segunda instancia, como un prócer quien, a pesar de todo, se mantiene leal a la lógica dictatorial que intentó retirar el yugo marxista del "ser nacional". Conjuntamente, esta figura también nos retrotrae a los grandes protagonistas de las narraciones oceánicas: José Ignacio Zenteno, Lord Thomas Alexander Cochrane, Manuel Blanco Encalada, Arturo Prat Chacón, entre varios. Casi como una metonimia, a través de su presencia podríamos hablar de la historiografía completa del héroe en Chile.

Finalmente, un tercer guiño que evoca al oficialismo es la paleta cromática general del tapiz. Desentendiéndonos del interior, la imagen se compone con los mismos matices de la bandera: el rojo, el blanco y el azul — con su variante celeste-. Juntos, los tres colores quiebran el código visual de los signos patrios: los mismos tonos que son empleados para conmemorar las glorias navales cada 21 de mayo y la primera Junta Nacional de Gobierno cada 18 de septiembre, acá son utilizados para corporeizar un nódulo en la historia, antecedente que, en forma de memoria prohibida (Pollak), podría llegar a desarticular por completo dicha remembranza. Notable es que el blanco característico de la Esmeralda sea representado en luminiscencia grisácea: se la describe opacada, despojada de su honor en tanto emblema de lo pulcro: "La blancura, síntoma de ingenuidad, limpieza y pureza que en algún momento puede haberle pertenecido a dicho barco, ya no le corresponde: ha sido manchada, mancillada" (J. Santos, "La reconfiguración” 151). Mas dicho gesto solo puede ser interpretado así una vez que lo enfrentemos con la escena interior de la arpillera. No cabe duda de que esta decisión cromática también pudo haber respondido a un tema de contraste: se prefiere ensombrecer lo que no tiene importancia para resaltar el cuadro decisivo. Como último alcance antes de avanzar, el blanco empleado para graficar el cadáver podría ser leído como una alegoría que resume a todos los cuerpos anónimos y perdidos, aquellos quienes continúan sin sepultura y disgregándose en los fondos recónditos del mar.

En un segundo nivel, la bodega del barco revela el aspecto funesto y el factor testimonial de la pieza. Tal como una ventana hacia un universo secreto, un corte longitudinal en el lado derecho inferior de la composición descubre la masacre. Absolutamente opuesto al relato heroico de afuera, aquí dentro aflora la mortandad en todos sus niveles: personas asesinadas, personajes vivos pero agonizantes y un sujeto encargado de dar muerte. Para evidenciarlos todavía más, incluso la clave cromática cambia: los colores patrios se mezclan con marrones y el mismo rojo bermellón, empleado en la bandera y en el marco tejido a crochet, ahora se utiliza en dos charcos de sangre que se escurren hacia la quilla de la Esmeralda. Son cinco o seis los personajes que estructuran el microrrelato. De ellos, uno es el verdugo, en color verde, quien sujeta entre sus manos lo que parece ser un soplete. En su cabeza distinguimos una suerte de capucha o simplemente trazos blancos aleatorios que solo nos comunican el enmascaramiento, 
y eventual impunidad, de los agentes de la dictadura. Inmediatamente a la derecha de aquel, encontramos una víctima que cuelga de las manos atadas a un muro. No vemos su rostro, ya que está de espaldas, pero alcanzamos a percibir pequeños puntos rojos: quemaduras producidas por la aplicación directa del fuego. Entremedio de estas dos figuras aparece un cuerpo impreciso realizado en tela rayada de colores blanco y rojo: podría tratarse de un difunto más, o bien de la sombra del sujeto torturado. Más abajo se muestra a dos individuos muertos o recién heridos: la sangre que emana de ellos los rodea. Finalmente, la última figura humana, a la izquierda y en color rosa, yace suspendida de pies a cabeza desde el techo: seguramente la próxima víctima del verdugo. Junto con ello, también vemos la inscripción textual de las fechas 1973, 1974 y 1976 en una mampara, biombo, o pared: los posibles años en los que el buque Esmeralda fue utilizado como centro de detención y/o tortura. Como se ha mostrado, la exégesis comparada de estos dos niveles refleja un abrupto descenso hacia el infierno: no hay mediación entre la cubierta y el horror, la inmediatez de las acciones militares sobreviene de un solo momento; aún la escalera misma, único lugar intermedio, participa de la catástrofe en cuanto es utilizada por el torturador para ejercer sus crímenes.

Como paisaje, esta arpillera hace resonancia con el género de las marinas: tópico imprescindible de la pintura canónica. Al respecto, Paulina Ahumada señala que en los albores de la joven nación existió la imperiosa necesidad de autorrepresentar la geografía soberana: "Crear una nación implicaba delimitar y describir el territorio [...]. Pero también había que contar una historia, un mito fundacional, que es lo que hace la pintura histórica" (138). Con esa finalidad en mente, distintos artistas se encargaron de modelar y esculpir el territorio en vista de los nuevos intereses geopolíticos de la inaugurada república. Mientras que Antonio Smith, Alejandro Cicarelli, Pedro Lira y Pedro Subercaseaux se preocuparon de describir, principalmente, la zona típicamente asociada al Valle Central cordillerano - complementando pictóricamente los notables aportes de los naturalistas del siglo XVIII y XIX-, otros desarrollaron un acabado estudio de las fronteras y los recursos marítimos, como fueron los trabajos de Thomas Somerscales y Álvaro Casanova. Si volvemos sobre la arpillera analizada, los elementos del océano Pacífico y los grandes navíos - retratados con porfía a lo largo de la historiografía nacional y universal- se tuercen al recibir un trágico barniz de crimen. Lo paradójico y punzante de esta dicotomía es que, a pesar de los antecedentes que presentamos, las marinas y las glorias navales siguieron y continúan participando insistentemente en la memoria oficial. Una clara demostración de aquello aparece en la figura 2: vemos tres series de estampillas que circularon en 1975, 1979 y 1986 respectivamente. Cada una de ellas, aunque semióticamente incomparables, actúa como una remembranza que eclipsa el relato que se propone en la arpillera. Cabe destacar que los buques allí graficados no siempre conciernen a la Esmeralda o a sus ancestros, sin embargo involucran la temática general de la reliquia del Pacífico y de la coraza impenetrable que socialmente simbolizan dichos barcos. En el conjunto encontramos las siguientes escenas y buques: la fragata Lautaro, el crucero Chacabuco, el bergantín 
FIGURA 2

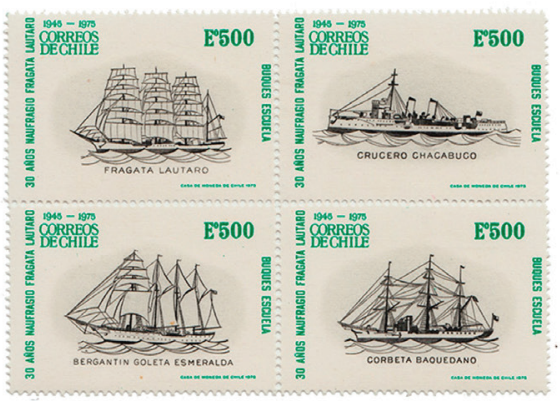

1975

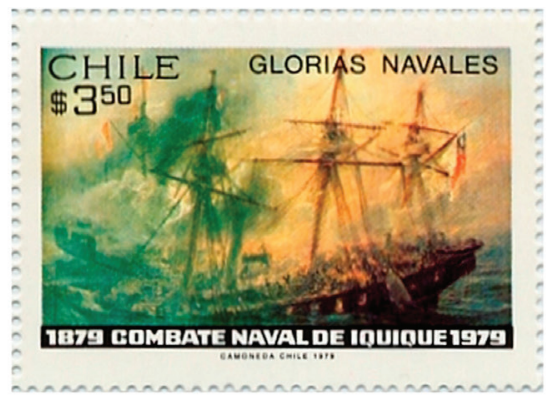

1979

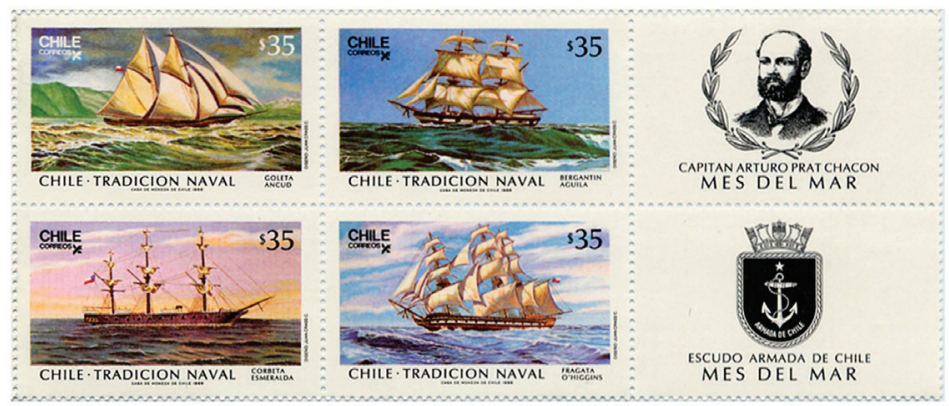

1986

Estampillas del periodo con temática naval.

Fuente: Archivo Museo Postal, Correos de Chile.

goleta Esmeralda, la fragata O’Higgins, la goleta Ancud, el bergantín Águila, el retrato del capitán Arturo Prat y un óleo de Thomas Somerscales referido al combate naval de Iquique. Pese a que resulta complejo saber si el régimen conocía o no el textil que revisamos primero, lo cierto es que estas representaciones oficialistas refractaron sus reclamaciones por la justicia hacia los confines de la epopeya. Al mismo tiempo, estas tres series de estampillas son solo pequeños atisbos de un conjunto mayor en el cual se exhibe una constante persecución de los ideales plásticos de antaño. Lo anterior también se condice con lo propuesto por Carine Lemeouneau: "La nación, en tanto idea abstracta, ha movilizado históricamente una serie de representaciones en torno a mitos fundantes y figuras activantes" (254). Como señalamos antes, la dictadura intentó legitimar su poder mediante figuras enaltecidas e incrustadas en el reservorio visual de la nación: hizo del paisaje su aliado para teñir de olvido a las memorias alternas y a los entornos reactivos a la política autoritaria. 


\section{FIGURA 3}
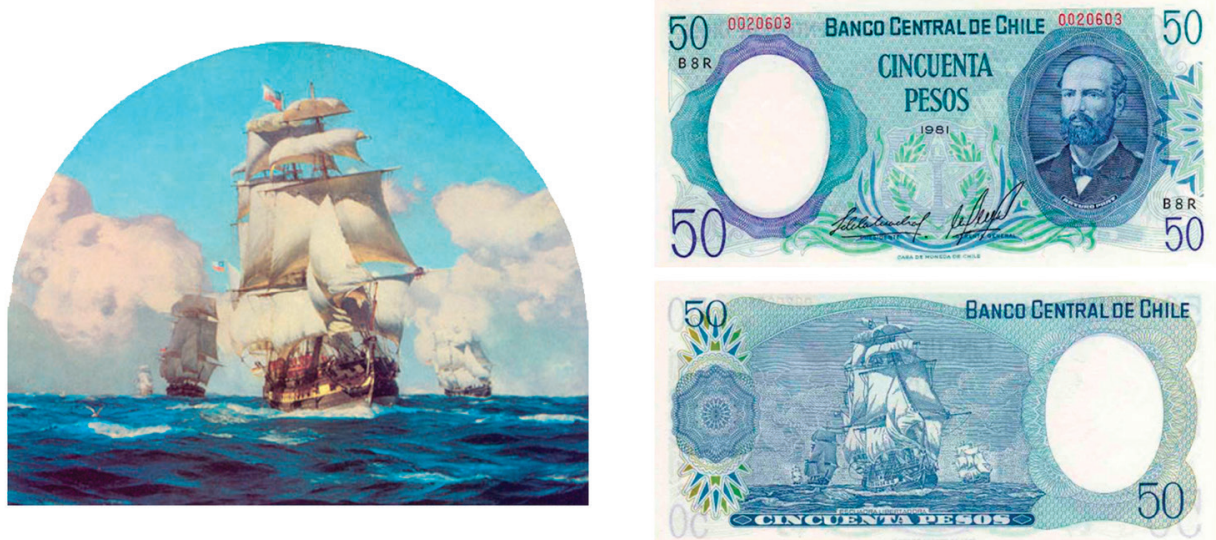

A la izquierda: La primera escuadra (1891) de Thomas Somerscales.

A la derecha: billete de 50 pesos (1981).

Otro ejemplo pertinente al caso es el billete de 50 pesos que se imprimió durante la dictadura. Su diseño recuperó el lienzo de Thomas Somerscales titulado La primera escuadra, que data de 1891 [figura 3] y que actualmente figura en el senado del ex Congreso. En aquel, se representa la primera flota de guerra de Chile, concebida durante la Patria Nueva, y que se conformó por el navío San Martín, la fragata Lautaro, la corbeta Chacabuco y el bergantín Araucano. Como podemos apreciar, varios de ellos también aparecieron en la producción filatélica del periodo [figura 2]. Asimismo, la figura de Arturo Prat y otros héroes fue un leitmotiv en la defensa visual del poder autoritario: mediante las glorias y los triunfos de la Independencia, adheridos a paisajes arquetípicos, se quiso instaurar la idea de una nación poderosa y liberada una vez más del invasor. Lo interesante a observar es cómo un mismo tópico es construido según voluntades opuestas, al servicio tanto de las operaciones de resistencia como al alero de la oficialidad. En definitiva, aquí queda perfectamente expreso que el paisaje no es tanto el referente, sino la interpretación afectiva e instrumental que se deposita sobre lo material y geográficamente dado.

\section{Crímenes, represión o violencia situada en lugares indeterminados}

Otra forma recurrente de denuncia fue la creación de escenarios imprecisos, en los cuales se montó buena parte de la exuberante diversidad de crímenes y mecanismos represivos. Por sus vínculos directos con lugares específicos, los dibujos realizados 
en centros de detención y/o tortura no forman parte de esta subcategoría. Esto no quita el hecho de que sí existieran dibujos independientes a un lugar fijo, o cuyo minúsculo vestigio geográfico sea indescifrable o incapaz de perfilarnos su sector de origen. No obstante, las arpilleras son más claras al respecto. Igualmente es factible que varios de los tapices que responden a esta función sí hayan sido confeccionados, en un principio, con el fin de reconstruir y referir la violencia que aconteció en parajes exactos, sin embargo, a diferencia de la subcategoría anterior, en estas imágenes no se expresa ningún atisbo, pista o señal de ruta clara que nos permita reconstruir la espacialidad geográfica que abrirían dichos lugares. Por consiguiente, la ausencia de referencia agrega cierto valor de universalidad parcial a estos testimonios: a falta de geolocalización, esta tipología de relatos permite vislumbrar una panorámica global de los fenómenos que subsumían al país en aquel periodo. Así, las dinámicas del horror que se describen son partícipes de una matriz reiterativa: pronostican un clima de constante atropello y violación a los derechos humanos que no distinguió las fronteras invisibles de las regiones. La inexactitud referencial acusa justamente que las acciones del terror se aplicaron todavía más allá de los sectores que el régimen consideraba potencialmente "peligrosos" o insurrectos: esparcieron su manto de miedo en todo el territorio. En consecuencia, el paisaje describe componentes comunes a casi cualquier rincón de Chile tales como montañas, edificios, casas, el océano y las costas, las villas o las poblaciones, en fin. Es decir, bajo la mirada de las arpilleras, todo sector podía transformarse en un sitio de amenaza, el suelo mismo era un sustrato cómplice de la dictadura: se abría a sus juegos.

A modo de ejemplo, trabajaremos con dos especímenes. El primero de ellos es la arpillera titulada Libertad atropellada [figura 4]. El textil muestra una escena de extrema violencia, una redada, que acontece en un barrio o población indeterminada. A partir de las tres casas sin rasgos extraordinarios, identificamos este sitio como un lugar residencial cualquiera. Sabemos, de todos modos, que podría tratarse de una comuna periférica de Santiago o de otra urbe, sin embargo, ningún antecedente explícito nos ayuda a confinar este paisaje. Como sea, distinguimos en ella a trece figuras humanas entre las cuales encontramos tres agentes de la dictadura golpeando a la mujer quien ocupa la posición central de la composición. Ella se sujeta del pañuelo, bufanda o barba de un hombre, quizás su esposo, quien además de expresar una clara mueca de dolor en su rostro, a la vez intenta frenar la caída de la mujer sobre un cesto de ropa o alimentos. Más abajo, se muestran ocho personajes que observan e intentan detener la acción de los militares. Algunos alzan directamente sus manos en contra de los agentes. Destaca uno de ellos, captado en tela color naranja hacia la derecha inferior de la composición, quien entre sus manos porta una herramienta o varilla que utiliza para atacar al militar: quizás un arma blanca. Por las diferencias de tamaño se puede deducir que la mujer posee una valoración mayor dentro de la comunidad; que los individuos más pequeños son los hijos y niños del barrio; o, simplemente, que la diferencia de escalas se utiliza para dirigir nuestra mirada al epicentro de la acción. 


\section{FIGURA 4}

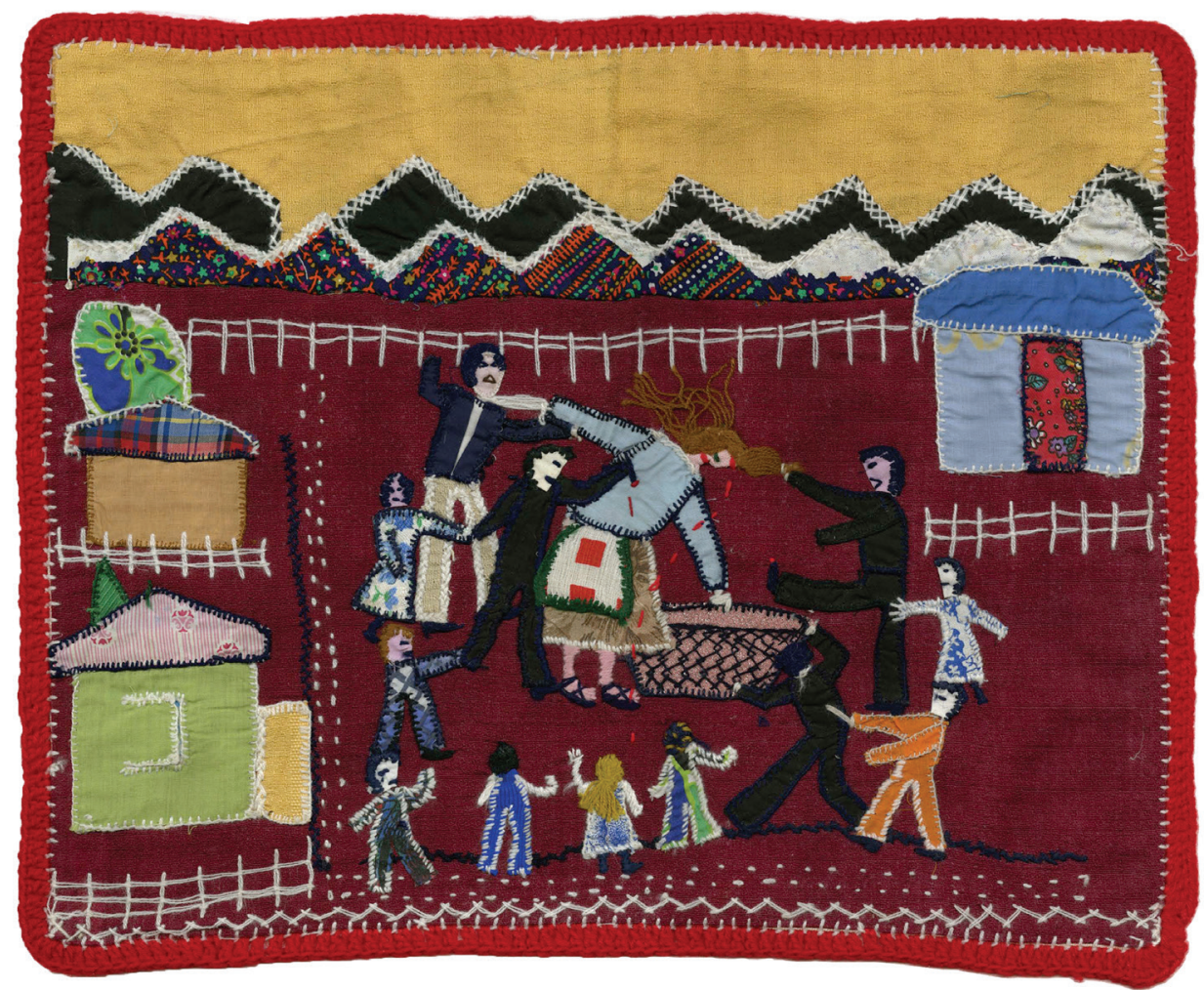

Libertad atropellada, 1974-1980 (Acumulación).

Fuente: MMDH, Colección Geneviève Jacques.

Uno de ellos, hacia la esquina inferior izquierda, llora ante la impotencia. La mujer enseña heridas sangrantes en la cabeza y en el torso, abiertas tras los efectos de un instrumento cortopunzante, las patadas y el tirón de cabello. Por la posición de los brazos y el ángulo de la columna de la mujer, notamos una clara resistencia ante el forcejeo. Uno de los militares situado justo debajo del cesto pareciera que intentara recogerlo o incautarlo: quizás presenciamos un allanamiento de mercancías o productos considerados peligrosos o ilegales. En esa perspectiva, la actitud de la mujer se transformaría en un intento feroz por evitar que los militares se lleven la cesta y los productos incógnitos que contiene.

Por otra parte, el paisaje poco nos revela sobre la condición del terreno. Atrás aparece la cordillera, ya sea de los Andes o de la Costa, y dos copas de árboles alcanzan 
a asomar tímidamente hacia la izquierda; tal vez fueron puestos así para no mitigar el efecto de violencia que acontece al medio. En forma lineal, tres cercas blancas y un trazado negro, quizás el límite de una cancha de fútbol, la plaza o el centro recreativo de la población, fortalecen la presunción de que este cuadro remite a la intromisión directa de la violencia jurídica en los espacios cotidianos. A diferencia de la arpillera anterior [figura 1], aquí la clave cromática no parece aportar a la significación del mensaje. Aun así, destaca el uso de los matices cálidos, generalmente asociados a la festividad, pero ahora utilizados para reflejar la dolencia y el quebrantamiento de los aparatos de resguardo: el hogar, la familia, los amigos. Ello se percibe ya que la saturación cromática de los tonos está más cercana al gris que al color puro. Entre un cielo ocre y un suelo carmín, la performance concreta del horror no deja especulación alguna: en la dictadura se violentó, se amedrentó, se maltrató, se intimidó, se humilló, se asesinó.

Un caso equívoco es la arpillera titulada La quema de libros [figura 5], la cual describe una gran fogata posterior al allanamiento e incautación de volúmenes sospechosos. La ambigüedad no es tanto por lo que describe - su mensaje es perfectamente

FIGURA 5

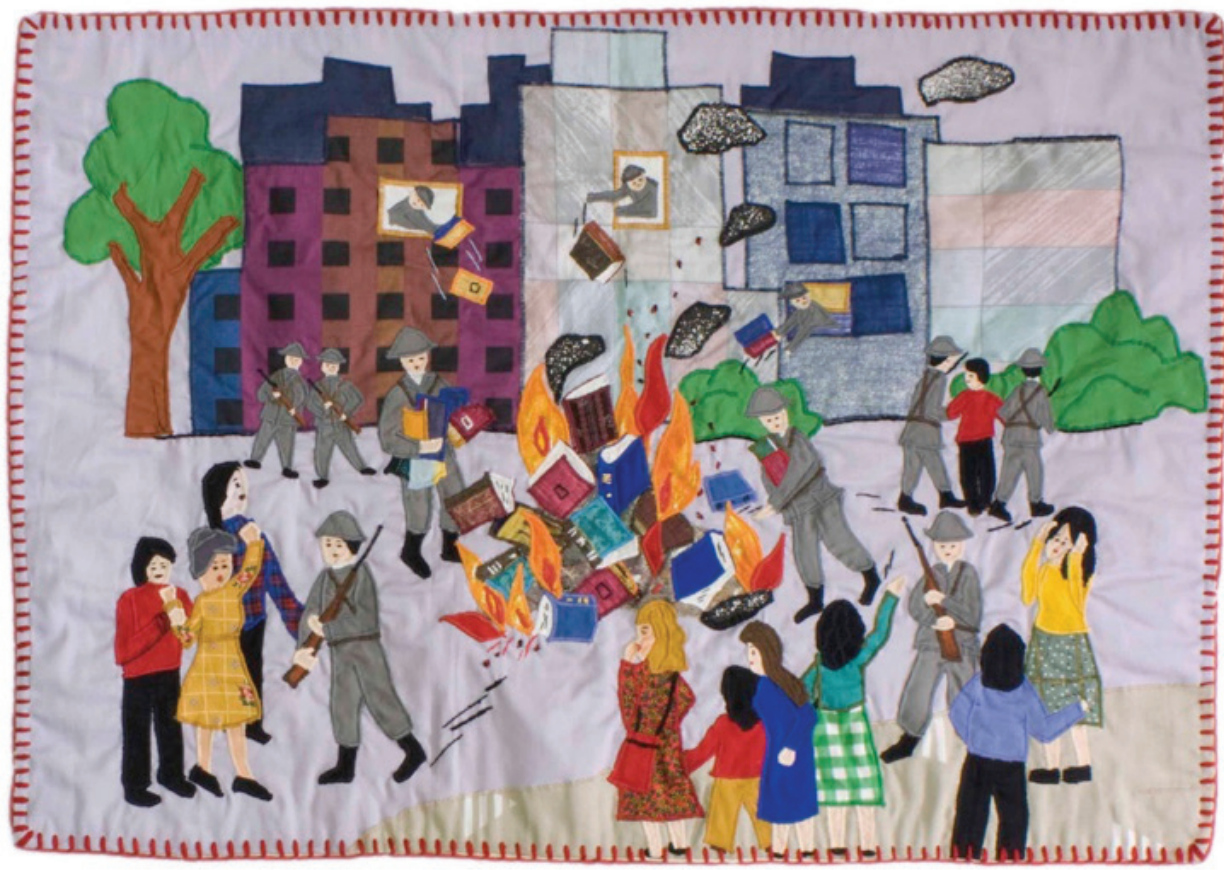

La quema de libros, 1973-1990 (Acumulación).

Fuente: $\mathrm{MMDH}$, Colección Isabel Morel. 
denotado-, sino por el lugar al cual remite: no lo podemos designar con certeza, aunque, evidentemente, no hay otro sitio más trágicamente icónico como lo fue la redada que aconteció en las torres San Borja. Aquel suceso particular, acaecido el 23 de septiembre de 1973 - día en que muere Pablo Neruda-, fue "la notificación de que cada familia debía revisar lo que tenía en casa; había que asumir que tener ciertos libros, discos o afiches podía ser peligroso" (Montealegre 203). En consecuencia, esconder, enterrar, quemar, perder o destruir revistas y libros comprometidos repercutió en una dinámica habitual dentro de los hogares de la población civil: el fuego penetró hasta los límites de la intimidad, así como otra de las tantas herramientas utilizadas en la operación limpieza que ejecutó la dictadura: “Quemar los vestigios de la Unidad Popular fue urgente para la dictadura. Y quemar era sinónimo de borrar, eliminar, hacer desaparecer" (204).

Volviendo a la imagen, pese a la pregnancia de los atentados ocurridos en las torres San Borja, los cuales fueron igualmente registrados en fotografías y videos, la arpillera no manifiesta ningún índice que garantice la alusión directa a dicho lugar: se presentan edificios, sí, pero bien podrían referir a cualquier otro allanamiento, y eventual quema, a lo largo del país. Por esta ambigüedad, prefiero evaluar esta arpillera desde su potencia indeterminada: nos sirve como reflejo de otros tantos actos de violencia simbólica.

Un primer aspecto que llama la atención de la arpillera es la diferencia numérica entre la fuerza armada y los civiles. Del total de veintiún figuras humanas, tan solo nueve corresponden a residentes o transeúntes, al tiempo que los doce restantes a militares. Lo anterior expresa una desproporción entre los actos admisibles por la autoridad: mientras el terrorismo de Estado y la brutalidad se consideran legales, se castigan violentamente hasta los mínimos gestos disidentes — como la tenencia de ciertas imágenes y libros—; es más, se aplican todos los recursos, una cantidad injustificada de militares, para castigar y criminalizar a los símbolos insurrectos y a sus portadores. Compositivamente, al fondo descubrimos las siluetas multicolores de los edificios: el paisaje urbano de la comunidad en llamas. Desde las pequeñas ventanas de los apartamentos emergen tres militares quienes arrojan libros hacia el suelo. Inmediatamente después, se sobrepone un plano en donde vemos la pira de fuero carcomiendo los fragmentos de la realidad indeseada por el régimen: las ideas resabias de la izquierda marxista. Algunos de los militares, los más cercanos a la llamarada, avivan la flama aportando con más libros. El resto de ellos vigila que nadie se interponga. De modo todavía más temerario, dos militares ubicados justo hacia la derecha superior de las llamas se llevan detenido a un hombre vestido de chaleco rojo y pantalones negros. La mirada de aquel civil, girada hacia la izquierda y dirigida hacia el fuego, podría insinuar la melancolía de la pérdida o, quizás, la angustia de no saber si volverá, si es que alguna vez retornará a ese paisaje. En un tercer nivel, algunas mujeres, notoriamente consternadas, alzan sus manos hacia el cielo en señal de protesta. En la esquina inferior izquierda, una mujer vestida de amarillo y quizás de edad avanzada — por 
el gris de su cabellera - empuña su brazo izquierdo mientras un hombre, tal vez un familiar, le sujeta con firmeza su otro brazo. La escena es tensa, puesto que mientras el hombre intenta detener las reclamaciones de la mujer, un militar se acerca desde la derecha con un fusil en mano: aquí la voz y la queja significan la muerte.

Otra mujer ubicada en la esquina inferior derecha, reconocible por su vestimenta superior amarilla y por su falda verde moteada de puntos blancos, sujeta su rostro con ambas manos en una clara manifestación de desesperación, impacto, pena, lamento. Entendemos esta actitud corporal como una respuesta física de la extrema violencia que significó la quema: ante los ojos de la comunidad pasaron las cenizas de los recuerdos transportados por esos libros y documentos. Como señala Jorge Montealegre, "La quema de libros no es solamente la destrucción de volúmenes materiales, la dimensión física de la publicación, sino que es un atentado a la memoria" (206). Además, cabe destacar que no solo se quemaron los libros relacionados con el marxismo, sino también aquellos cuyos títulos sonaran o se asemejaran en algún grado a los conceptos de izquierda (206). Finalmente, existe una contradicción entre los árboles frondosos y la vegetación, y las nubes negras que se alzan hacia el cielo. Los primeros ornamentan el paisaje transformándolo en lugar de contemplación y recreación, pero el humo negro, que emerge directamente de la combustión del recuerdo social, ensucia la afectividad arraigada a los espacios comunitarios. Las mismas nubes negras que en otros paisajes vaticinarían temporales y épocas de lluvia, aquí conforman un humo nebuloso de tragedia.

Al comparar ambos tapices notamos que los elementos utilizados son figuras comunes y fácilmente decodificables: ambas recurren al escenario de la vivienda como antípoda del estadio de paz ilusoria que intentaba promulgar el régimen. En efecto, para Randahl Morris las mujeres arpilleristas utilizaron la familiaridad de la vida privada como telón de fondo para tejer sus escenas y las contrastaron con imágenes directamente opuestas a la retórica del Estado como protector del pueblo (115). Así, ambos textiles demuestran que la sociedad se vio coartada ontológicamente de sus lugares íntimos. Aun cuando los parajes descritos pertenecían a áreas públicas de uso comunitario - la cancha y la planta de los edificios-, su uso estaba vinculado al desarrollo afectivo y colectivo de esos grupos, por tanto se involucraban con el aspecto privado de ese microuniverso social. Mientras la visión de la dictadura consideraba la propiedad privada en tanto objeto sacralizado del consumo, por otra parte la privacidad de la vida común fue profanada cual material biológico disponible. En consecuencia, eran considerados sujetos sin derecho a la recreación, a reír, a la libertad cultural, a la decisión política, a la mínima paz de sus lugares y moradas.

\section{Marginalización y escasez}

Un tercer mecanismo de denuncia fue utilizar el paisaje para evidenciar el desabastecimiento como una modulación alterna de la violencia de Estado. La extrema condición de penuria y la marginalización en la cual se mantuvo a los sectores vulnerables de las 


\section{FIGURA 6}

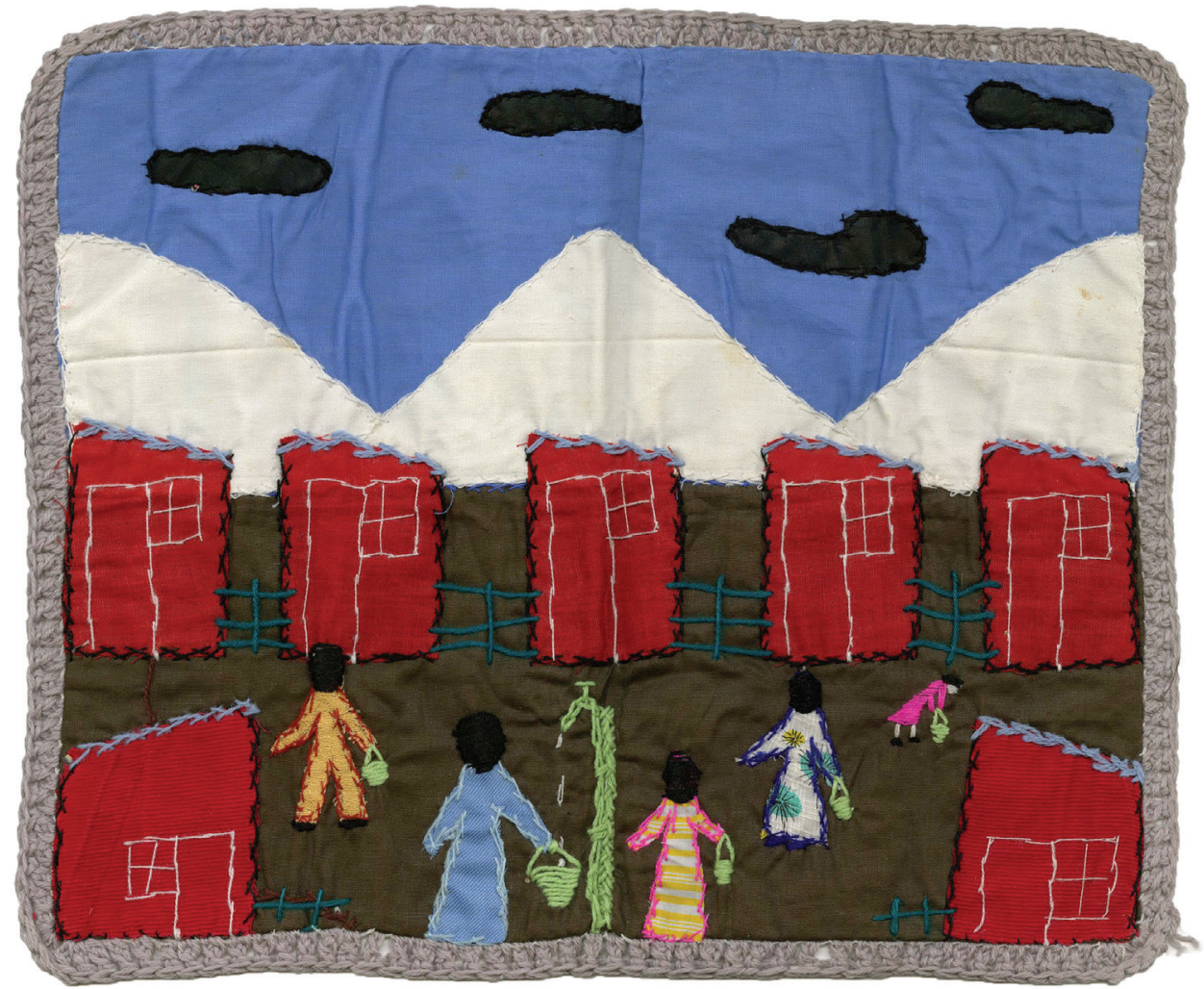

Escasez de agua potable, 1978.

Fuente: ммDH, Colección Carmen Waugh.

ciudades, y también el hacinamiento de los prisioneros al interior de los centros de detención y/o tortura, fueron relatos incisos al crecimiento económico y social del país: gracias a la miseria de extramuros en las urbes y las regiones, se generó la exterioridad suficiente para avalar y justificar el enriquecimiento de los otros. Jorge Rueda señala que entre 1973 y 1989 Chile profundizó la tradición de ser un país dividido por dos estamentos civiles en polaridad. Por una parte, las élites económicamente dominantes estructuraron una racionalidad de mercado. Por otra, los sectores poblacionales pobres percibieron de manera directa y masiva la incertidumbre y exclusión opresora (342). De ahí que los reclamos de varios paisajes no-oficiales expusieran la contracara del modelo económico. La exclusión-inclusiva de la sociedad se autorrepresentó mediante la exposición directa de sus precariedades: las limitaciones económicas y la falta de insumos básicos como la leche, o la inexistencia de locomoción y la evidente cesantía 
que sufrían las familias. Todos estos rasgos fueron interpretados por la habilidad textil de las arpilleristas, sin embargo, en el caso de los dibujos que remitieron a las condiciones paupérrimas del encarcelamiento, consideré que dicha función encajaba mejor con la descripción física de los centros (siguiente subcategoría). Entonces, junto con denunciar las circunstancias insalubres e indignas del cautiverio, los dibujos actúan como antecedentes probatorios de una vida y un lugar interior escondido.

En la figura 6 vemos a cinco personajes - al parecer tres mujeres, un hombre y una niña- quienes sujetan cinco baldes para el agua. El escenario es una pequeña villa de siete casas rojas en donde distinguimos unas cercas de color verde petróleo y, al medio, un grifo de agua del cual se escurren un par de gotas. La tierra es yerma: a diferencia de las arpilleras anteriores, notamos la ausencia total de vegetación en una extendida tierra oscura. En el fondo se impone la cordillera con todo su esplendor blanco y nevado: la potencialidad de un hielo perpetuo que no se derrite, que no discurre su agua montaña abajo. Exceptuando una mujer o niña pequeña vestida de color magenta hacia la derecha, no vemos el rostro de los personajes: están girados y solo nos comparten sus espaldas y cabelleras negras. Arriba vemos un cúmulo de cuatro nubes negras que contrastan fuertemente con el tono cian del cielo. En esta composición, llamada Escasez de agua potable, el paisaje y los actores presentes transmiten la profunda pesadumbre de la miserable carestía. Lo que parece ser una circunstancia típica de barrio, se nos revela como una situación de súplica y anhelo: bajo esta lectura, las miradas volteadas de los sujetos contemplarían con expectación

FIGURA 7

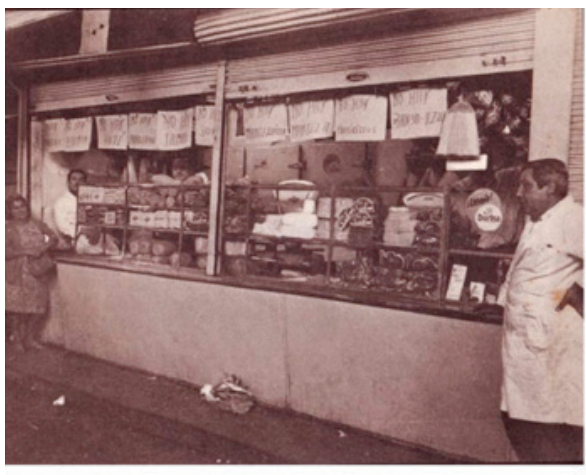

Ayer

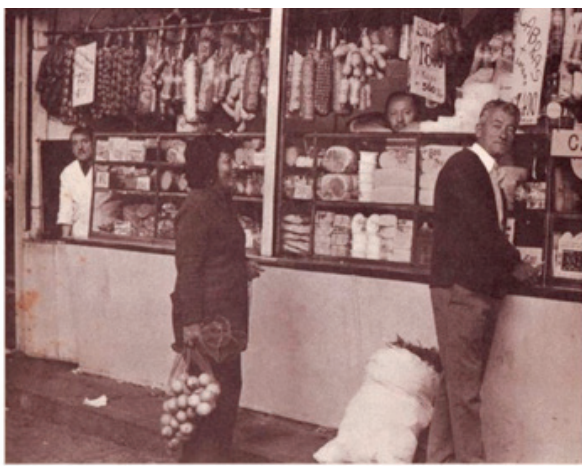

Hoy

Escasez versus abundancia. Fuente: Chile ayer hoy. Santiago, Editora Nacional Gabriela Mistral, 1975. 
y ansiedad la llegada siempre tardía de la lluvia. En términos testimoniales, acá se hace patente una escritura paradójica de la sequía: la cordillera es representada con la misma lejanía que el acceso al agua u otros recursos fisiológicamente esenciales. También, tanto las nubes negras - cargadas de riqueza líquida - como la cordillera -el cordón montañoso que protege la nación - proyectan un aura inaccesible: la naturaleza no salva al pueblo que percibe y que habita ese paisaje. La monumentalidad de dichos signos, en tanto fuerzas geofísicas, hace caso omiso de la sed. Es más, aquello que se volvió natural al entorno fue el inmutable estado de vulnerabilidad de los sujetos: no se sabe si se podrá comer o beber mañana. Todavía más allá, la arpillera parece haber sido plasmada a partir de la ironía: aquello preciado, ansiado, anhelado e imprescindible es puesto justo a la vista de quienes más lo necesitan, sin embargo, es dejado fuera de su alcance.

Para complejizar esta interpretación, contemplemos la incongruencia que sugiere la figura 7: se muestran dos paisajes contrapuestos de un mismo lugar, pero marcados irrenunciablemente por los efectos del quiebre político: hacia la izquierda se ilustra la escasez del periodo marxista. En la fotografía, vemos un negocio mal proveído y una serie de carteles escritos a mano que lo confirman: no hay jamón, no hay mantequilla, no hay manteca, etcétera. A la derecha, aparece el mismo local, mas esta vez bien suministrado gracias a los beneficios inmediatos de la dictadura: la supuesta abundancia que trajo consigo el régimen. Bajo la óptica dictatorial, hoy sí hay pan, sí hay cecinas, sí hay variedad y, aún más, clientes felices. Ambas fotografías fueron puestas en tensión dentro del libro Chile ayer hoy, orquestado por el régimen mediante el sello de la refundada Editora Nacional Gabriela Mistral. ${ }^{4}$ El dramatismo que se observa fue característico de las imágenes del oficialismo, sobre todo porque sus combinaciones semánticas servían también para explorar el miedo al comunismo o para hurgar temores más íntimos (Jara, "Graficar" 147). Aunque se trata de un lugar cerrado, posiblemente la Vega Central, la intención y la transfiguración del contexto - de la pobreza a la riqueza - permiten interpretar estas imágenes como paisajes de la vida común. En estos, se pretendió justificar la acción dictatorial incluyendo a los actores de la clase media y trabajadora: al demostrar la drástica mejoría comercial no solo se confirmaba la reactivación del mercado, sino que también se asumía como un síntoma del beneficio global que abrazaba al país.

Finalizando, en la filatelia también encontramos varios ejemplos de la codiciada abundancia del nuevo orden. Gonzalo Leiva y Luis Errázuriz consideran que "la estampilla puede ser vista como una pizarra que ayuda a ir dando forma a una identidad nacional, a partir de determinados valores [...] que los distintos gobiernos deciden poner de relieve" (89). Según los autores, el tratamiento político de la estampilla sería

4 Es bastante probable que se trate de montajes fotográficos específicamente producidos para inducir el efecto. Sin embargo, no cuento con los datos suficientes para aseverar esta conjetura. 
FIGURA 8

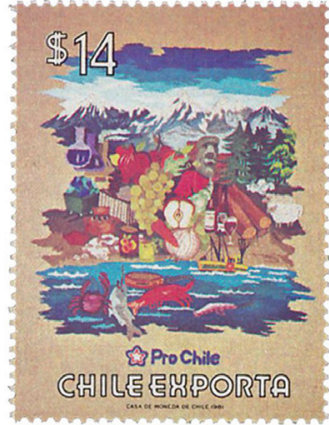

1981

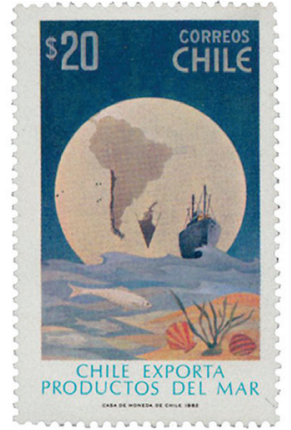

1982

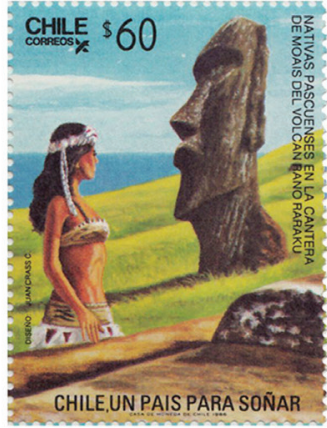

1986

Estampillas del periodo.

Fuente: Archivo Museo Postal, Correos de Chile.

mucho más inmediato que la manipulación de otros medios como los billetes o los monumentos públicos. En la figura 8 he seleccionado solo tres de ellos. La primera estampilla, de 1981, describe un paisaje de acumulación: vemos la cordillera nevada, los productos agrícolas nacionales, los frutos del mar, los bosques, un matraz, barriles de combustible, entre tantos. La estampilla, además, va rotulada con un notorio "Chile exporta”. Del mismo modo, en la segunda ilustración, de 1982, se levanta un paisaje que alude concretamente a la exportación de insumos marítimos. En ella destaca una luna llena sobre la cual se dibujó la soberanía geopolítica del gobierno. Hacia delante distinguimos un buque, olas y peces, a la vez que su rótulo confirma lo que se aprecia: “Chile exporta productos del mar". En tercer lugar, la estampilla de 1986, rotulada como "Chile, un país para soñar", introduce la construcción del país como destino turístico. En ella vemos la cantera de moais del volcán Rano Raraku junto a una bailarina, signos arquetípicamente pascuenses. En general, cada una de las estampillas selectas quiso señalar las potencialidades financieras y extractivas del país, además de intentar proyectar una imagen renovada y turística de la nación.

Con todo, al tomar en cuenta las representaciones oficiales del periodo, la arpillera analizada adquiere un peso legítimo ante la extrema desigualdad que presumen ostentosamente las políticas mercantiles. Analizados desde la riqueza y la abundancia, los productos y los frutos de la naturaleza que salen de Chile dejan una llaga abierta sobre los individuos subalternos que no tienen qué beber, con qué suplir la cuota básica de alimento que demanda la existencia. Presenciamos una escala de contrastes que no deja lugar a grises: la abundancia irrisoria del régimen aplana abruptamente a la hambruna que padecen los sujetos vulnerados. Por estas razones, los paisajes 
de resistencia batallaron para testimoniar los verdaderos estragos de la economía: mediante esas acciones tenía sentido pelear la vida.

\section{Descripción física de edificios o entornos}

Tal como adelanté, esta subcategoría atañe principalmente a los dibujos realizados al interior de los centros de detención y/o tortura. El motivo principal de la discrepancia recae en el nivel de detalle al cual se podía llegar según los distintos medios y materiales propios a cada tipología. De este modo, el dibujo se prestó para realizar un examen analítico de los inmuebles y parajes que configuraban el horizonte inmediato de los centros de detención. Por otra parte, el sigilo y el hermetismo de las prisiones clandestinas agrega más valor probatorio a los dibujos que a las arpilleras, las cuales graficaron principalmente lugares de acceso público o bien sectores privados que eran vistos desde un afuera constitutivo: la mirada inconfundible del espectador. Aquí es importante no malinterpretar el giro hermenéutico que propongo: las arpilleras, en

\section{FIGURA 9}

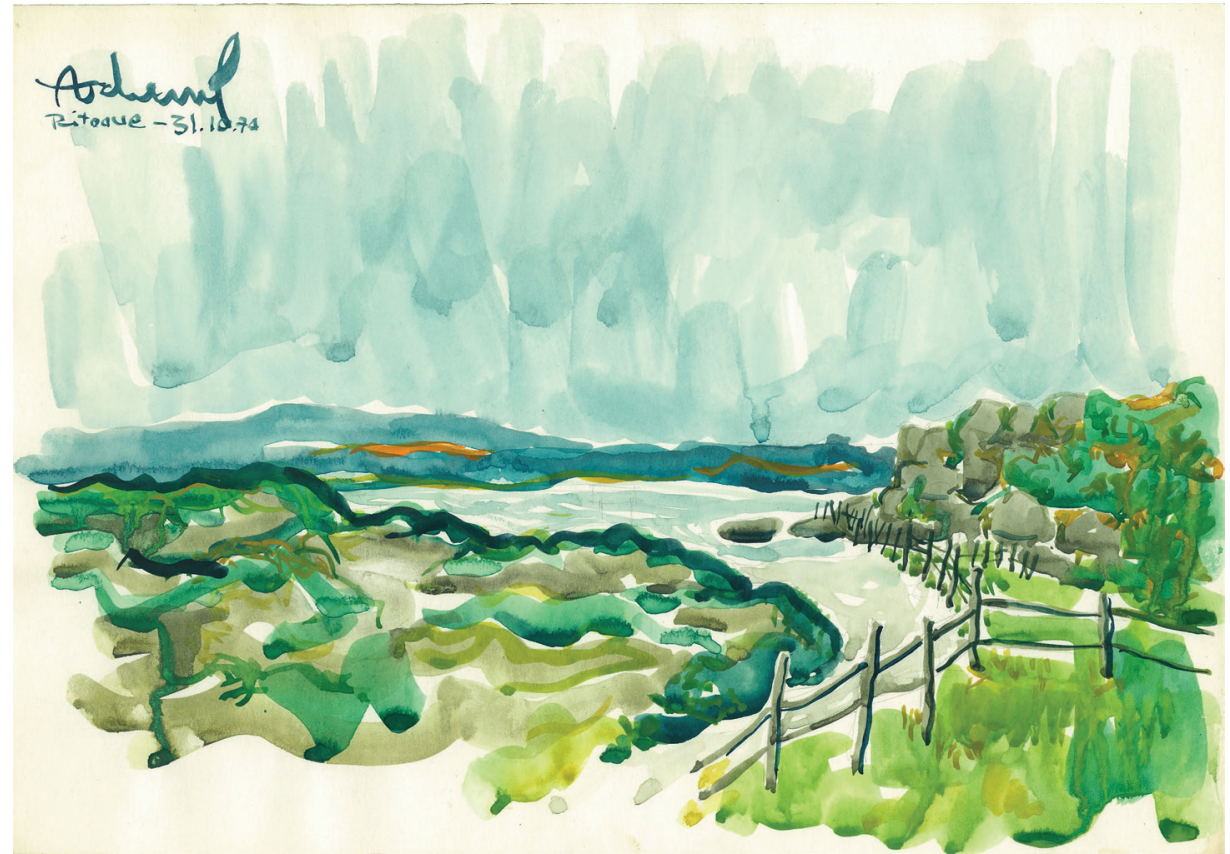

Vista de Ritoque, 31 de octubre de 1974.

Fuente: MMDH, Archivo Adam Policzer. 
efecto, testimoniaron la presencia de crímenes situados tal como lo analizamos en la primera subcategoría [figura 1]. Sin embargo, la radiografía física de los lugares entregada por esos textiles no se comparó a la otorgada por los dibujos: estos, al contrario, indagaron hasta en la planimetría de los cimientos. Dejando a un margen el problema de la veracidad mesurable de dichos diagramas, los dibujos en prisión sí lograron fotografiar - aunque subjetivamente - una meticulosa y atractiva panorámica arquitectónica y espacial. Aclarado esto, la descripción física de edificios o entornos presenta tintes o grados de subjetividad que vale la pena mencionar: el primer eslabón responde a la configuración afectiva de la naturaleza, se retrata principalmente lo que se ve hacia fuera del recinto; el segundo nivel, a modo intermedio, implica la mirada meticulosa de la arquitectura circundante, generalmente identificada por vistas en perspectivas y coherentes a la visión del ojo humano; en un tercer nivel están los dibujos que describen matemáticamente los espacios abiertos por los lugares del horror. Aquí encontramos proyecciones depuradas y vistas isométricas.

La primera imagen [figura 9] es una acuarela sobre papel que representa la naturaleza de los alrededores del campamento de prisioneros de Ritoque, realizada por Adam Policzer durante su reclusión en dicho recinto. El dibujo, o pintura, destaca por el uso de aguadas en matices fríos que van desde el azul hacia el verde, con apariciones intermitentes de naranjas y amarillos. A pesar de la temperatura del color, la imagen transmite serenidad e incluso dicha, o al menos emotividad. Esto es deducible a partir de la armonía cromática general y según un trazo impresionista que construye desde la mancha su estabilidad referencial: el verde de aquel instante se captura según la percepción irrepetible del momento. Así, se observa fácilmente cada pincelada, realizada con la rapidez que le es propia a este medio líquido, al tiempo que también notamos varios sectores de acumulación pictórica. Sobre el autor, cabe resumir que tuvo formación de arquitecto en la Universidad de Chile, lo cual, ciertamente, ayudó a la concreción visual de la acuarela a partir de los croquis que se realizan en las aulas del taller, ejercicios transversales a la instrucción de cualquier escuela de arquitectura. También destaca su participación política con la Juventud Demócrata Cristiana y su posterior militancia en el Partido Socialista. De su cautiverio, podemos acotar que pasó por los centros de Ritoque y Chacabuco entre 1973 y 1975, año en el cual finalmente es exiliado ( $\mathrm{MMDH}$, Dibujos 54-59). Visualmente, la imagen transmite cierto deleite referido a la contemplación desinteresada de la naturaleza. Acá es pertinente comparar la funcionalización oficialista que tuvo este mismo tópico: la dictadura interpretó la geografía desde lo canónico y lo monumental, por tanto describió una naturaleza distante y de corte heroico. La acuarela de Policzer, al contrario, se aproxima mucho más al referente que retrata; no hay epopeya que separe al espectador-creador de la realidad física que ilustra. Desde otra arista, el lugar interpretado podría describir a las inmediaciones de la desembocadura del río Aconcagua o algún estero de Mantagua. Ahora bien, es factible extraer estos datos a partir de la firma e inscripción del autor, ubicada en la esquina superior izquierda de la composición. Sin ella, lo más probable 


\section{FIGURA 10}

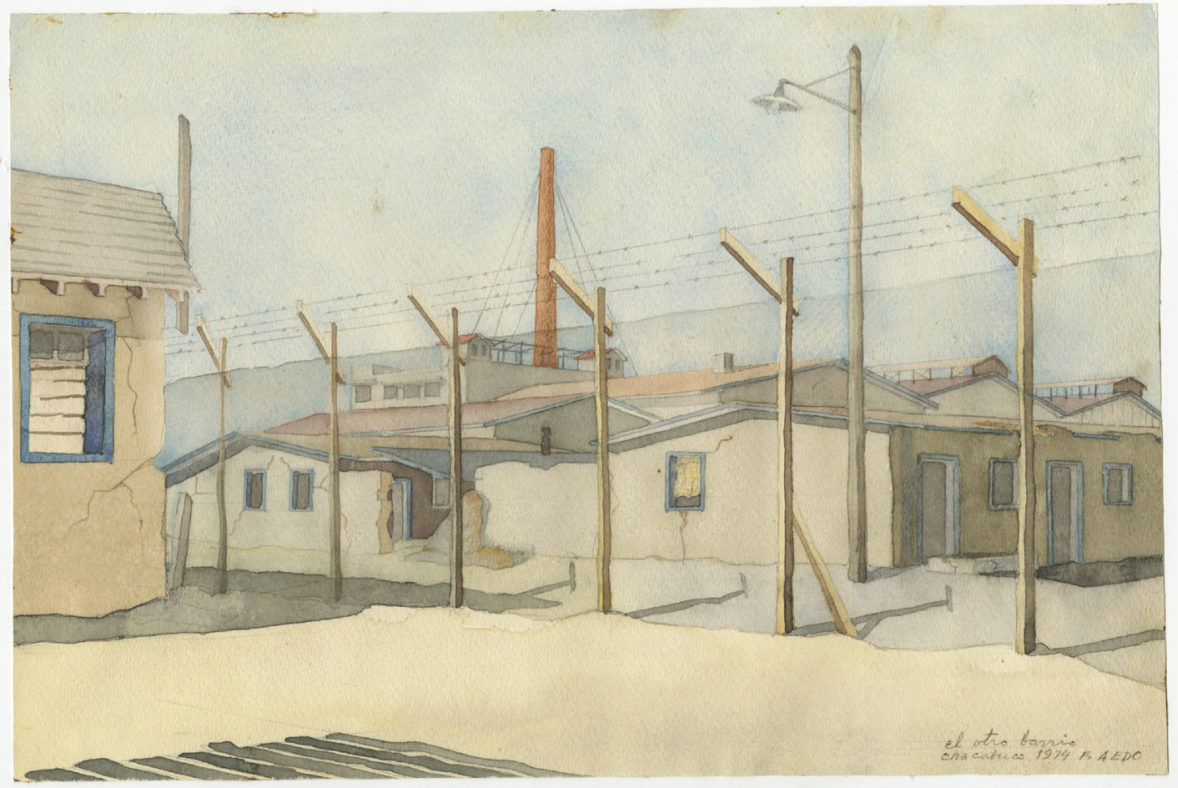

El otro barrio, 1974.

Fuente: MMDH, Archivo Francisco Aedo.

es que la imagen resultara equívoca, difícilmente asignable a un lugar en particular: esas dunas costeras, el riachuelo, el humedal, la empalizada y la vegetación podrían referir a muchas otras latitudes de Chile. Este factor hace que la acuarela evoque más a la emergencia por reconstruir la afectividad perdida del lugar que a un mapeo cabal de la circunstancia. No obstante, preferí trabajar esta imagen aquí pues participa de esos paisajes "internos-externos" de los sitios de detención y/o tortura. Antes de caer en contradicción, considero esos paisajes como aquellas imágenes que se construyen desde el interior del horror "mirando hacia fuera". El prisionero no goza de libertad, en lo absoluto, pero alcanza a capturar estas fugacidades en donde la naturaleza y el paisaje se avecinan a tal punto que parecieran simular una escapatoria. Un ejercicio testimonial atingente a esta composición sería verificar cuáles fueron las coordenadas específicas desde donde se originó la vista del paisaje.

Continuando, en la figura 10 vemos otra acuarela, esta vez pintada por Francisco Aedo. Al igual que Policzer, Aedo inició sus estudios de arquitectura en la Universidad de Chile. Su posición política se vinculó con el Partido Socialista y más tarde colaboró con el Movimiento de Izquierda Revolucionaria. Estuvo detenido al menos en tres 
lugares: el Estadio Chile, el Estadio Nacional y Chacabuco. Luego de ser liberado y nuevamente arrestado, permanece detenido desaparecido (ммDн, Dibujos 10-12). Sobre la imagen, ella describe una postal paradójica de Chacabuco en la medida que la excelsa técnica y los cuidadosos detalles transmiten, por el contrario, una profunda desolación y abandono. Mientras el paisaje queda representado en festivos matices cálidos - quizás estamos cerca del mediodía - la imagen nos revela murallas agrietadas, rejas y alambres de púas. Siguiendo las constataciones de José Santos, esos sistemas se seguridad se enmarcan dentro de las operaciones de reacomodo que fueron realizadas para reconvertir las construcciones existentes en centros de detención y/o tortura. Según cuenta Alberto Gamboa, Chacabuco fue transformado, de antigua oficina salitrera a lugar del horror, en solo cuatro semanas: "a las rejas las coronaron con alambre de púas electrificadas. Y construyeron altas torres de madera con techumbre, donde la guardia armada vigilaba día y noche a los detenidos para impedir que se escaparan" (cit. en J. Santos, "La reconfiguración" 157). Así, corroboramos parte de esas instalaciones dentro de la acuarela. También verificamos la oposición entre las nuevas infraestructuras y las antiguas, si miramos con detalle, aflora un contraste cálido-frío que intensifica las grietas de los inmuebles viejos. En suma, la abandonada salitrera muestra dos capas de memorias atrapadas: el decaimiento de la vivacidad antaña y la imposibilidad de resurgir tras su tétrico nuevo uso. Pese a ello, la descripción del entorno es aguda -herencia de la experticia arquitectónica de su autor-y nos permite recomponer la atmósfera que presenciaron los ojos del dibujante. Este tipo de imágenes actúa principalmente como testimonio de la rutina interior que vivían las o los prisioneros en los centros de detención. También demuestra la existencia de esos centros y parte de la distribución y gestión de los mismos. El grado de subjetividad, aunque mucho menor que la acuarela anterior, no está necesariamente oculto: existe una melancolía y una sensación de vacío que orbita en la imagen. Pareciera que visitamos un lugar sin huéspedes, un desierto en medio del otro desierto. Resulta interesante verificar cómo la desolación del dibujo de Aedo también se repite en la acuarela de Landy Grandón [figura 11], quien fuera miembro del Partido Comunista y sobreviviente de la reclusión en el Estadio Nacional, Chacabuco y Tres Álamos (ммDH, Dibujos 37-39). Su composición, al igual que la de Aedo, trabaja con una descripción mimética del entorno observado pero mediante un contraste cálido-frío más intenso. A la vez, se repite la fricción entre las dependencias viejas y una tabiquería abandonada o en pleno proceso de construcción: quizás las maderas que futuramente soportarán una alambrada. Como sea, el tratamiento gráfico de ambas acuarelas oscila entre la objetividad escénica y la subjetividad fantasmagórica, la aridez y la dicha, la libertad y el cautiverio. Otro factor común es la proximidad del referente. Lo retratado se encuentra a pocos metros de distancia, o es interpretado así, lo cual implica una cercanía concreta con el horror. A diferencia del paisaje de Ritoque, cuya distancia focal fue utilizada para representar la lejanía idílica de la libertad y el goce de la naturaleza, acá el encierro trunca la perspectiva, obligando a pensar en lo que se tiene al frente. 


\section{FIGURA 11}

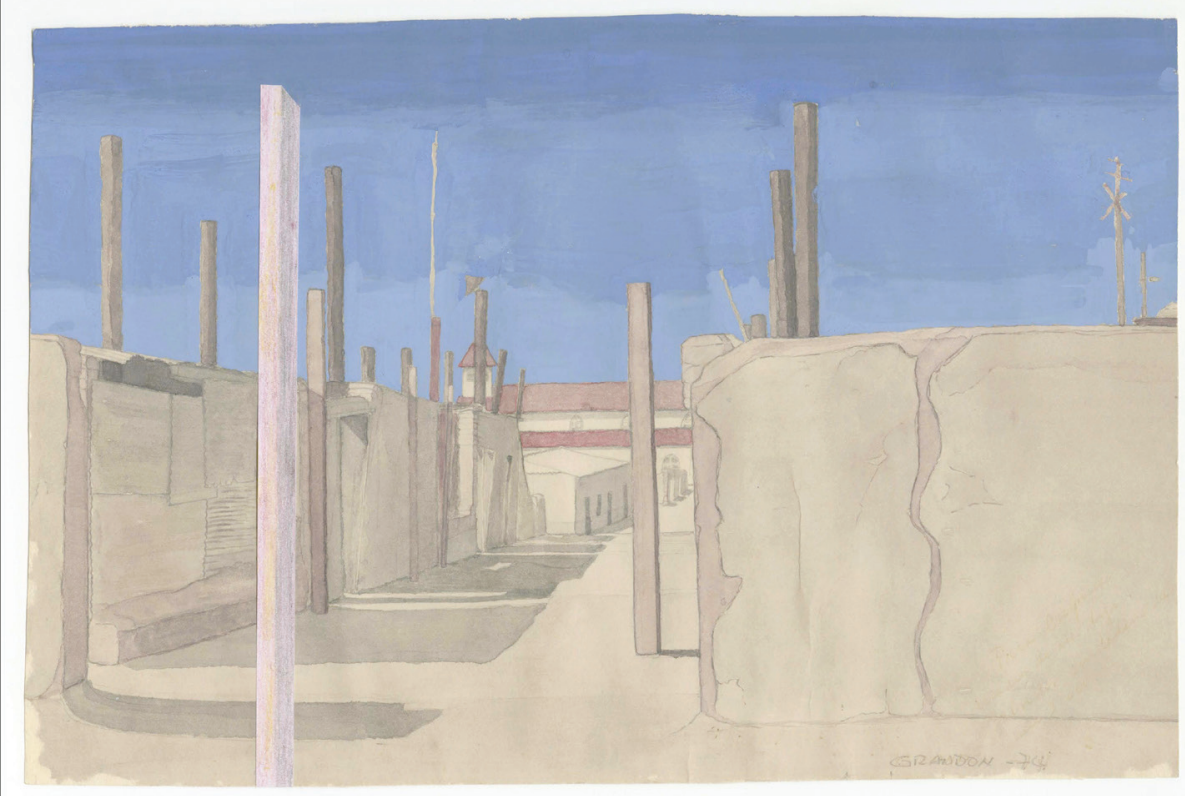

Campamento de prisioneros Chacabuco, 1974.

Fuente: MMDH, Archivo Landy Grandón.

Finalmente, el tercer nivel de esta subcategoría involucra una cantidad no menor de planimetrías o dibujos técnicos de los edificios y entornos. La figura 12, por ejemplo, es un dibujo de Ricardo Cruz que ayuda a reconstruir la disposición, el hacinamiento y la subdivisión del espacio en la Penitenciaría de Santiago. El entonces también estudiante de arquitectura de la Pontificia Universidad Católica de Chile realizó una larga serie de dibujos durante el periodo de al menos dos semanas que duró su reclusión en dicho centro (MMDH, Dibujos 30). A diferencia de los dibujos anteriores, estos fueron precarios, trazados con velocidad y principalmente configurados a partir del dibujo de contorno y el achurado. Según cuenta el autor, los insumos gráficos fueron infiltrados por los familiares mediante frazadas y otras encomiendas. Específicamente, la figura presenta un diagrama que se divide en tres zonas o niveles. Arriba y en el centro se ubican descripciones longitudinales de la Penitenciaría, abajo se describe isométricamente, y desde una posición cenital, las dimensiones de una celda o sala. El valor testimonial que agrega esta imagen es la cuantificación del entorno circundante: se anotaron las presuntas distancias entre los distintos edificios, la altura y los usos de los mismos, además de la disposición humana dentro de las celdas: 5 personas 


\section{FIGURA 12}

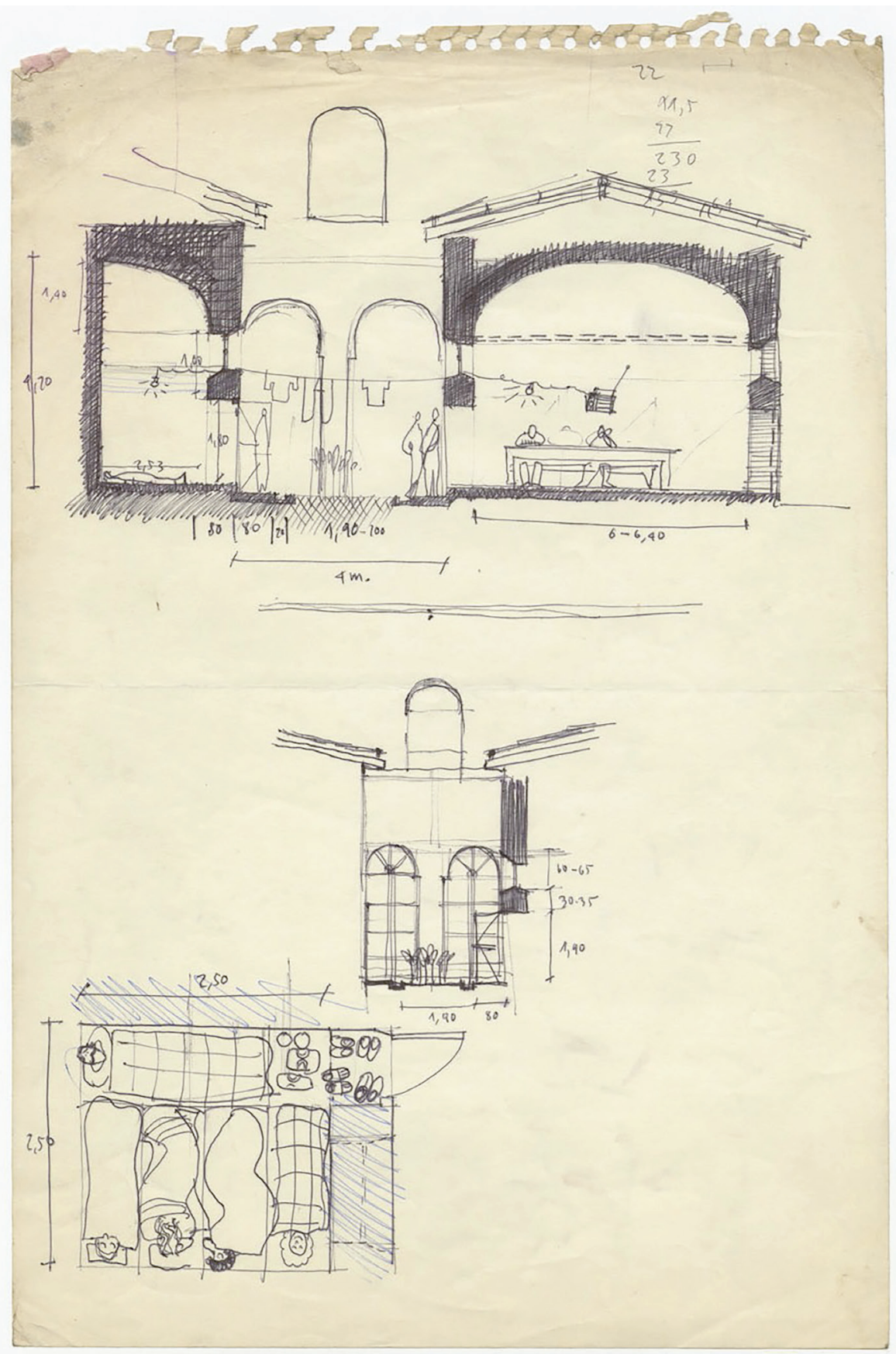

Diagrama del interior de la cárcel (Penitenciaría de Santiago), 1980. Fuente: $\mathrm{MMDH}$, Archivo Ricardo Cruz. 
durmiendo en una habitación de 2,5 metros cuadrados, dejando espacio para la ropa y los zapatos. Si bien no queda claro cómo fueron obtenidas dichas medidas, lo más lógico sería pensar que fueron mesuradas mediante pasos, pulgadas, cantidad de manos, longitudes del brazo u otras instrumentalizaciones del cuerpo.

En suma, las representaciones que se condicen a estos lineamientos capturan la condición material y la forma terrible mediante la cual se apiñaba a los presos dentro del cautiverio. A diferencia de los paisajes anteriores, en estos dibujos no existe color ni pretensión estética directa. Asimismo, la subjetividad pareció esconderse: por el contrario, se intentó fijar la "realidad" concreta del recinto. A la vez, la proxémica fue vivencial: se retrató lo que estaba encima, lo que se respiraba y se palpaba. Retrospectivamente, a medida que los paisajes retrataban con mayor cercanía sus referentes, se visualizaba un intento cabal por asir la objetividad de los cimientos y los lugares de un modo matemáticamente verificable. A la vez, la afectividad depositada en el trazo y en el color se tornó procesualmente menos relevante, hasta que finalmente se difuminó, mientras que la descripción analítica o formal de los entornos adquirió el peso protagónico del dibujo: la naturaleza era soñada y ansiada, por tanto se reflejó mediante una cargada gestualidad; pero el hacinamiento de la prisión fue ineludible, por tanto se interpretó mediante una abandonada subjetividad y la evidencia precaria de los lápices y papeles con los que se trazaba.

\section{Conclusiones}

Llegados a este punto, resulta innegable que el paisaje, como objeto de estudio, desborda el enfoque puramente artístico o telúrico con el cual se suelen trabajar sus insumos. Tras el estudio logramos poner en relieve sus múltiples recovecos, silencios y sombras: la imagen paisajística, desde su configuración visual, desplegó categóricos testimonios e interpretaciones. En retrospectiva, lo que se hizo fue corporeizar una narración hecha imagen cuya voz, muchas veces considerada superflua, enhebró su propio curso de acción; nos guiamos según los códigos que ya habían sido dibujados e hilvanados muchos años atrás. Mediante la denuncia y la evidencia pudimos percibir paisajes que testificaron los sucesos situados en lugares específicos y, por el contrario, entrevimos cómo el terrorismo de Estado no distinguió límites o fronteras a través de las geografías indeterminadas. Del mismo modo, esta función no solo evidenció la violencia física, sino que también puso en vista la escasez y la marginalización como otras formas de opresión política. A la vez, encontramos dibujos que nos aportaron minuciosos detalles sobre los cimientos y la gestión interna de los centros de detención y/o tortura: antecedentes que sirvieron tanto como expresiones de la subjetividad así como pruebas irrefutables de la existencia de dichos sitios.

Aun así, después de haber expuesto numerosas evidencias gráficas, advertimos que el paisaje esconde y revela mucho más que las fronteras trazadas por sus formas: 
denuncia, subvierte, suscita, alienta, emociona, señala, demanda. Con todo, pudimos apreciar que el paisaje fue utilizado cual mecanismo defensivo ante las estrategias doctrinarias de la dictadura. Y todavía si dichas imágenes no fueron originalmente pensadas así — como paisajes-, las arpilleras y los dibujos reclamaron una posición directamente contraria al relato heroico-refundacional que implantó el oficialismo. En su lucha por la dignidad, el derecho a la justicia y la vida misma, las representaciones no-oficiales graficaron los espacios de modo tal que no quedara duda alguna: la dictadura utilizó el país como sustrato para emplazar y propagar su mortandad. Es más, se demostró que varias imágenes disidentes, al deslizarse sigilosamente fuera del control y la vigilancia, visibilizaron una textura espacio-referencial declarativamente quebrada desde el binomio lugar-experiencias.

Para concluir, el propósito esencial de este estudio fue recoger una tipología no necesariamente vinculada con las problemáticas de la memoria, de modo tal que pudiésemos ampliar las perspectivas de análisis y diversificar los recursos para rearticular la tragedia. Gracias a esta iniciativa pudimos aportar con una aproximación distinta del corpus seleccionado: en vez de un objeto inexplorado, analizamos insumos de conocimiento público pero que no habían sido estudiados bajo el alero del paisaje. De este modo, quisimos entregar una modalidad legítima, aunque alterna, al discurso testimonial en Chile. Solo queda continuar desarrollando, bajo esta misma metodología, otras funciones pendientes: por una parte, distinguir cómo estos paisajes ayudaron a generar redes de apoyo y solidaridad mediante la interpelación; y, por otra, en qué medida fueron útiles al momento de reconstituir las subjetividades quebradas tras el trauma. Así — defendiendo el valor testimonial de la imagen-, el océano, la cordillera, los edificios y los barcos no serán más accesorios ilustrativos de un discurso textual, sino que, con toda la autoridad que merecen, podrán dar cuerpo a las narrativas propias que cuidadosamente guardan sus contornos.

\section{Referencias}

Ahumada, Paulina. "Paisaje y nación: la majestuosa montaña en el imaginario del siglo XIx”. Una geografía imaginada. Diez ensayos sobre arte y naturaleza. Ed. Amarí Peliowski y Catalina Valdés. Santiago, Metales Pesados, 2014, pp. 113-142.

Armada de Chile. Historia. 30 de diciembre de 2017. Disponible en https://www.esmeralda.cl/esmeralda/buque-escuela-esmeralda/historia/2014-06-04/113135.html

Beverley, John. "Anatomía del testimonio". Revista de Crítica Literaria Latinoamericana, n. ${ }^{\circ} 25,1987$, pp. 7-16.

Errázuriz, Luis. "Dictadura militar en Chile. Antecedentes del golpe estético-cultural". LARR, Latin American Research Review, vol. 44, n. ${ }^{\circ}$ 2, 2009, pp. 136-157.

Errázuriz, Luis y Gonzalo Leiva. El golpe estético. Dictadura militar en Chile 1973-1989. Santiago, Ocho Libros, 2012. 
Jara, Isabel. “Graficar una 'Segunda Independencia’: El Régimen Militar Chileno y las ilustraciones de la Editorial Nacional Gabriela Mistral (1973-1976)”. Historia, n. ${ }^{\circ}$ 44, vol. 1, 2011, pp. 131-163.

- - "Politizar el paisaje, ilustrar la patria: nacionalismo, dictadura chilena y proyecto editorial". Aisthesis, n. ${ }^{o}$ 50, 2011, pp. 230-252.

Leiva, Gonzalo. "Memoria cultural fundacional de la dictadura militar en Chile: sus repercusiones en el ámbito de la práctica creativa (1973-1983)”. Cadernos de estudos culturais, vol. 5 , n. ${ }^{\circ} 10,2013$, pp. 89-114.

Lemouneau, Carine. "Las trazas de la naturaleza en dictadura: formulaciones a propósito de un arte nacional”. Una geografía imaginada. Diez ensayos sobre arte y naturaleza. Ed. Amarí Peliowski y Catalina Valdés. Santiago, Metales Pesados, 2014, pp. 251-271.

Maderuelo, Javier. El paisaje. Génesis de un concepto. Tercera edición. Madrid, Abada, 2013.

Montealegre, Jorge. "Cenizas de la memoria: testimonio sobre censuras, autocensuras y desobediencia”. Revista Anales, 6, 2014, pp. 199-210.

Morris, Randahl. "From Healing to Hope: The Continuing Influence of the Chilean Arpilleras". Kritika Kultura, 26, 2016, pp. 107-129.

Museo de la Memoria y los Derechos Humanos. Arpilleras. Colección del Museo de la Memoria y los Derechos Humanos. Santiago, Ocho Libros, 2012.

- - Dibujos en prisión. Colección del Museo de la Memoria y los Derechos Humanos. Santiago, Ocho Libros, 2014.

Nogué, Joan. “Sentido del lugar, paisaje y conflicto”. Geopolítica(s), vol. 5, n. 2, 2015, pp. 155-163.

Pollak, Michael. Memoria, olvido, silencio. La producción social de identidades frente a situaciones límite. Buenos Aires, Ediciones Al Margen, 2006.

Rueda, Jorge. "Risa y resistencia en las poblaciones de Santiago de Chile: 1973-1989". Intersecciones en Antropología, vol. 14, n. ${ }^{\circ}$ 2, 2013, pp. 341-352.

Santos, José. "La reconfiguración como el modo de llegar a ser. Surgimiento de los centros de detención y/o tortura en el Chile dictatorial”. Aisthesis, n. ${ }^{\circ}$ 60, 2016, pp. 145-165.

- - " "Los centros de detención y/o tortura en Chile. Su desaparición como destino". Revista Izquierdas, n. ${ }^{\circ}$ 26, 2016, pp. 256-275.

Santos, Milton. La naturaleza del espacio. Técnica y tiempo. Razón y emoción. Barcelona, Ariel, 2000.

Tanács, Erika. "El paisaje: un texto para leer". Memoria y sociedad, vol. 7, n. ${ }^{\circ}$ 14, 2003, pp. 19-27.

Enviado: 20 de abril de 2018

Aceptado: 12 de junio de 2019 